\title{
Learning Innovation for Character Education in Global Era: Methods and Assessments
}

\author{
Mirsa Istiharoh \\ Department of Social Studies \\ Universitas Negeri Yogyakarta \\ Yogyakarta, Indonesia \\ mirsaistiharoh.2017@student.uny.ac.id
}

\author{
Setyabudi Indartono \\ Faculty of Economy \\ Universitas Negeri Yogyakarta \\ Yogyakarta, Indonesia \\ setyabudi_indartono@uny.ac.id
}

\begin{abstract}
Character education is addressed for preparing young generation to be more ready in facing some global challenges. In the implementation of character education, the right method and assessment are needed in order that the learning runs maximally. This article aims to describe innovation of method and assessment which can be used to support learning process of character education. This present research utilizes qualitative approach. The type of this research is literature research. The data are taken from some articles, journals, and books. The result of this research reveals that there are some learning methods that can be used to support learning process of character education such as: conversation method, story, promise, role-model providing, and habituation. Besides, the assessment processes that can be used in character education cover project assessment technique, portfolio, observation, selfassessment, and interview. The contribution of this present research is for all education practitioners especially teachers who involve directly in the implementation of character education both in formal and non-formal education institutions.
\end{abstract}

Keywords-innovation, character education, global era,
methods and assessment

\section{INTRODUCTION}

Globalization era is an era in which the development of computer and internet technology encounter a significant enhancement. This technology advancement accelerates the exchange of goods and services, community mobility, information access, and knowledge. In education field, namely education management system (information system, selfevaluation, governance, performance report, and so forth) and learning process has been using computer and internet applications. In the class context, the existence of internet provides learning model in network with various designs, like web-based learning, virtual learning, virtual class, mobile learning, blended learning, and so on [1]; [2]. The use of learning models in network has accelerated learning process of the students. Even in a context, the use of computer and internet in management system of education and the learning implementation become one of advancement parameters of education institutions.

However, its existence is not without problems. Global era has also brought wide moral impacts, mainly for young generations. The existence of internet has grown instant mentality for the students, fraud, and defamation through social media network; free sex, and others which are conflicting with the values of culture and religion which is believed. This leads individuals to the understanding degradation of belief, moral, and culture values. Thus, the education, which is run, should not only be oriented on moral knowledge and moral feeling, but also it should be oriented on moral action (competency, willingness, and habit) [3]. This target demands changes on implementation and assessment in learning. The implementation of learning focuses on the use of method and the strategy of learning in which character values had and understood by the students, starting from limited environment (family, class, and school) to a wider environment (community and nation). The method and the learning strategy which support the appreciation of character values are strengthened by the learning assessment system which is in accordance with character education.

The assessment system that supports the growth and the development of character values in individuals themselves demand innovation in orientation, process, and technique/form of assessment. Assessment orientation is not only on the measurement of learning result as the learning evaluation in general, but also it should be on the betterment of curriculum or learning process, the guidance of learning phases, and learning motivation for students [4]; [5]. It is supported by the continuity and technique or form of assessment which is authentic and various. The continuity of assessment can be conducted during learning process and out of learning process. Afterwards, authenticity and diversity of assessment technique can be in form of project, portfolio, observation, self-assessment or reflection, and interview [6]; [7]. This writing aims to describe character values in the students, the changes of method and assessment system of learning which is innovative in education character which is considered being able to support the growth and the development of character values in this global era.

\section{THE CONCEPT OF CHARACTER EDUCATION}

Jonathan Webber in Journal of Philosophy explains that Character is the accumulation of some features appearing in the way of thinking, feeling, and acting [8]. The courageous person or the coward of someone in facing difficult times, the anxiety in facing many people, are the simple examples of someone's 
Character. It is in line with the formula expressed by Victor Battistch from University of Missouri St. Louis, in one of his writings entitled Character Education, Prevention and Positive Youth Development, emphasizes that Character is the constellation which is extremely wide among attitude, action, motivation, and skill. Character involves attitude, action, way of thinking, and response towards injustice, interpersonal and emotional, and commitment to do something for community, nation and country [9]. As Webber, Battistich also thinks that Character is always faced with good and bad, done or not done by someone. Doing good deeds means having good and ideal character; on the contrary, doing bad deeds means having bad character. According to Philips, character is a set of values leading to a system, which is the base of thinking, attitude, and action, which are performed [10]. Character, according to Thomas Lickona in Glanzer, is "knowing the good, desiring the good, and doing the good" [11].

Thomas Lickona mentions seven essential and main characters that must be transferred to the students covering: honesty, compassion, courage, kindness, self-control, cooperation, diligence or hard work [12]. In the academic transcript of Development of Cultural Education and Nation Character (Pengembangan Pendidikan Budaya dan Karakter Bangsa), The Ministry of Culture and Education of the Republic of Indonesia has formulated more character values (18 values) which will be developed or given to the students and young generation of Indonesia, such as: religiosity, honesty, tolerance, discipline, hardworking, creativity, independence, democratic, curiosity, nation spirit, homeland affection, achievement appreciation, friendliness / communicativeness, peace-oriented, reading-oriented, environmental care, social care, and responsibility [13].

Besides, in the main form of Character Education, The Ministry of Culture and Education of the Republic of Indonesia has also explained character configuration in the context of psycho-social and socio-cultural process in four big groups, namely: spiritual and emotional development, intellectual development, physical and kinesthetic development, and affective and creativity development [13] Furthermore, regarding to the ways to teach the values, Thomas Lickona provides an explanation that there are three significant components in building character education which are moral knowing (knowledge about more), moral feeling (feeling about moral) dan moral action (acting based on moral).

Afterwards, the mission or the target that must be had in character education, covering: First, cognitive, brain knowing, teaching it from not knowing anything to know everything, and in the next phases, the students can habituate thinking so that they are able to function their brain to be intelligence quotient.
Second, affective; it is related to feeling, emotion, and attitude building in someone's personality with the forming of attitude, sympathy, antipathy, loving, hating, and others. All these attitudes can be grouped into emotional quotient. Third, psychomotor: it is related to action, behavior, and so on. Thomas Lickona mentions five approaches in planting character education, such as: value planting approach, cognitive planting approach, value analysis approach, value clarification approach, and action learning approach [12].

Lickona, Schaps, and Lewis in CEP's Eleven Principles of Effective Character Education explain eleven basic principles in supporting the success of character education implementation [12]. The eleven principles are: 1) School community develops ethics and main competence values as the base of good character: 2) School defines character comprehensively to insert thinking, feeling, and behavior; 3) School uses comprehensive, intentional, and proactive approaches to the character development; 4) School creates community caring about character; 5) School provides an opportunity to the students to perform moral action; 6) School proposes meaningful and challenging academic curriculum which appreciates all students in developing their characters and helping them achieve success; 7) School develops self-motivation of the students; 8) Schools staffs are the ethics-learning community which share responsibilities in conducting character education and inserting main values directing to the students; 9) School develops collective leadership and great support towards the beginning or the betterment of character education; 10) School involves family members and community as the partner in the attempt of character building; 11) School regularly assess and measure culture and climate, the functions of staffs as the character educators and in what extend the students are able to manifest good character in daily association [12].

\section{LEARNING METHOD}

Method is one of the strategies or the ways which are used by teachers in learning process which is willing to be achieved. The better the method used by a teacher, the better the learning will be. Sudjana assumes that method is a whole plan to provide language learning material regularly, there is no confliction part, and all is based on approach. Axiomatic approach is an approach which has been guaranteed its truth, while procedural approach is an approach which is done by implementing phases. Procedural method means that the implementation of learning is done through regular and systematic phases started from the arrangement of learning plan, teaching, teaching-learning process, and learning result assessment [14].

According to Sangidu, method is a way of working which has a system to begin the implementation of an 
activity in order to achieve goals which have been set in the beginning [15]. Salamun explains that learning method is different ways to achieve learning result which are different under different conditions. It means that the selection of learning method must be in accordance with the learning condition and the learning result that will be achieved [16].

Based on those opinions, it can be concluded that learning method is a complete and a systematic plan in providing learning material. Learning method is done regularly and gradually with different ways to achieve goals under different conditions. The use of learning method is extremely essential because with method, the teachers can plan a complete and a systematic learning process in providing learning material. The types of learning method are such as: a) tutorial method (the learning management conducted is through guidance process); b) demonstration method (the learning management is by demonstrating or showing process, situation, thing, or procedure); c) debate method (enhancing students' academic competence); d) Role Playing method (the way of mastering learning material is through the development of imagination and comprehension); and e) problem solving method [14].

Some learning methods which can be chosen by the teachers contextually such as: 1) Scientific learning method is the learning method which is based on the process of science with the activity phase started from formulating problems, formulating hypothesis, collecting data, analyzing data, and making a conclusion; 2) Inquiry/discovery learning method is research / revealing; 3) Problem-based learning method is the learning method focusing on identification and problem solving which is real, practical, contextual, in the form of problem in which its structure is unclear or not yet clear of having the solution in the students' life as the central point of teaching to be solved through scientific procedure in learning in which its activity is done by group; 4) Project-based learning method is a learning which uses project as media in learning process to achieve the competence of attitude, knowledge, and skill; 5) Cooperative learning method is a learning model in which the students learn in small groups with heterogeneous membership; 6) Text-based instruction/genre-based instruction method is a learning which is oriented on students' competences in arranging texts [17].

\section{LEARNING ASSESSMENT}

According to Gronlund \& Linn, assessment is a systematic process and covers activity of collecting, analyzing, and interpreting information to determine how far someone has achieved the learning purposes which have been set previously. Hopkins and Antes assume that assessment is a continuous investigation to obtain information including teachers, students, education programs, and the decision exactness about the overview of students and the effectiveness of program [18]. Assessment is a systematic process which has collection of information, analysis, and interpreting of the information to make conclusions. In other words, education decision is made based on the results of analysis and interpretation of information collected. The collected information can be in form of number though test, or verbal description (through observation) [19]. Education assessment is considered as the process of collecting and analyzing information to measure the achievement of students' learning results. The assessment covers: authentic assessment, self-assessment, portfolio-based assessment, examination, daily examination, middle test, final test, competence examination, competence-quality examination, national examination, and school examination [13]. There are some assessment types in learning, which are:

First, it is attitude assessment [17]. Attitude assessment is an assessment towards the tendency of stuents' behavior as the result of education, both in the classroom or out of the classroom. Attitude assessment has different characteristics from knowledge and competence assessment, so that the assessment technique used is also different. In this case, attitude assessment is addressed to know achievements and to guide behavior and attitude of students based on attitude points in basic competence. Attitude assessment is done through observation recorded in the journal in form of anecdotal record and incidental record. Assessment techniques cover: 1) Observation; in students' attitude assessment, it is a technique used continuously through very good (positive) or less good (negative) behavior observation which is regarding to indicators of spiritual attitude and social attitude; 2) Self-assessment; it is an assessment by asking students to express strengths and weaknesses of themselves in behaving. The result of students' self-assessment can be used as confirmation data. Self-assessment can give positive effect towards the development of students' personality; 3) Interstudents assessment; it is an assessment done by asking students to assess their own friends one another. Like self-assessment, the result of interstudents' assessment can also be used as confirmation data [17].

Second, it is knowledge assessment [17]. Knowledge assessment is an assessment which aims to measure students' competence which cover factual, conceptual, procedural, and metacognitive knowledge and thinking competence from low to high. Knowledge assessment is done by some assessment techniques. The teachers choose assessment technique which is in line with the competence characteristics that will be assessed. The assessment is started from planning which is done when arranging Learning Plan (RPP) which referes to syllabus. Knowledge assessment besides to know whether students have achieved mastery learning, it also aims to identify 
weaknessess and strengths of students' knowledge mastery in learning process (diagnostic). Therefore, feedback for students and teachers are essential so that learning result can be used immediately for the betterment of learning quality [17].

Assessment technique in knowledge competence can be used in accordance with characteristics of each basic competence. The techniques which are commonly used are: 1) Written test; a test in which its questions and answers are provided in written form to measure or to obtain information about competence of test participants. Written test demand response from participants which can be used as the representation of the competence that they have. The instruments of the written test can be in form of multiple choice, essay, short answer, correct-incorrect, pairing, and explaining; 2) Oral test; the questions demand students answering by oral and can be given classically when learning. The students' answers can be in form of words, phrases, sentences, or paragraphs. Oral test grows students' attitude to express their opinions bravely; 3) Assignment; the assignment for students aims to measure and/or improve knowledge. The assignment used to measure knowledge competence (assessment of learning) can be done after learning process, so that the assignment that is used to improve knowledge (assessment for learning) is given before and/or during learning process. The assignment can be in form of homework and/or project which is done individually or in group based on task characteristics. The assignment is more focused on problem solving and other productive tasks. However, other techniques can also be used like portfolio and observation [17]

Third, it is competence assessment [17]. Competence assessment is an assessment aiming to measure students' competence achievement towards basic competence. Competence assessment demands students demonstrating a particular competence. This assessment aims to know whether the knowledge which has been master by students can be used to know and solve problems in real life. Competence assessment can be done by several techniques namely: 1) Performance assessment is used to measure the learning achievement in form of process competence and/or result (product). Performance assessment focuses on result (product) which is commonly called product assessment, while performance assessment which focuses on process and product is called practical assessment. The aspect assessed in performance assessment is the process of working or the quality of product or both; 2) Project assessment is the activity of assessing a project which includes activity of designing, implementing, and reporting what has been accomplished period. The project can be in form of an investigation starting from planning, data collection, organizing, processing, and data providing. The project assessment can be used to know comprehension, the ability of applying, innovation and creativity, the ability of investigating, and students' competence in informing particular learning subjects clearly; 3) Portfolio assessment is the continuous assessment which is based on a set of reflective-integrative information which reveals the development of students' competence in a particular period. There are some types of portfolio namely documentation portfolio, process portfolio, and exhibition portfolio. The teachers may choose type of portfolio which is in accordance with the characteristic of basic competence and/or the context of the subjects [17].

\section{THE IMPORTANCE OF METHOD INNOVATION AND LEARNING METHOD IN CHARACTER EDUCATION}

Character education can be understood as an intentional attempt to develop good deeds in individuals which influence thinking pattern, attitude pattern, and action pattern in the real life. Character education attempts to guide students to understand, expect, and do goodness, regarding to themselves and others as well as environment and God. Character is related to self because someone who has good character is able to guide himself to decide something in a good and in a right way. Character is related to other people and environment because a good character only appears in a relation or interaction with other people or environment. Character is related to God because the teaching about goodness is always related to religion preaching; besides it is also because naturally God is Always Good.

There are three aspects of someone character building systems, namely: 1) moral knowledge covers knowing moral values, knowing other people's perspective, moral reasoning, and courage to make decisions; 2) moral feeling includes listening to heart, self-esteem, empathy, goodness loving, self-control, and compassion; 3) moral action covers competency, willingness, and habit [3]. The success of character education can form good habits on students. A good personality is formed through process of knowing, expecting, and doing good deeds [3].

Character education encounters education field approximately since 1990s when Thomas Lickona wrote a book of The Return of Character Education dan Education for Character: How Our School Can Teach Respect and Responsibility [3]. The imperative of character education in Indonesia was begun in 2000s when the government set National Long-Term Development Plan (RJPN) in 2005-2025. In the Plan, character education is places as the base of national development vision manifestation. In 2010, The Ministry of National Education launched three guides, namely: 1) Guide of Character Education in Junior High School, 2) Main Design of National Education Ministry's Character Education, and 3) Reference Framework of National Education Ministry Character Education [20]. 
It gives an effect on national curriculum change. In Competence-Based Curriculum in 2014 and Schoolbased curriculum in 20016, character education was inserted to all subjects, so that a sub-point appeared in Learning Plan (RPP) in form of "the expected character". In Curriculum of 2013, character education is integrated with Religion Education with the name of Religion Education and Good Character. It is related to the implementation of nine priority agendas in the governing period of Joko Widodo and Jusuf Kala in 2014 in the figure of "Nawacita", especially in the agenda number eight which is "Performing nation revolution character through re-arrangement of national education by prioritizing citizen education aspect, which places education aspect proportionally, like the teaching of nation forming history, patriotism values, homeland loving, nation defending spirit, and good character in the education curriculum of Indonesia'. The Minister of Education and Culture publishes Minister Regulation Number 23 of 2005 regarding the Growing of Good Character; then in 2016, it became The Strengthening of Character Education through One-Day School Implementation.

Although the essence and the target of character education are like moral education in the subject of Civic and Religion Education, but, both subjects are not optimal yet in building good character for students. The reason is both subjects tend to focus more on academic aspect than behavior and good habit aspect. It can be seen from the process of learning and the system of national education assessment.

Innovation of method and learning assessment in character education are considered important because many life behaviors of children, teenagers, and adults nowadays are not in line with the values of nation struggle. [20]. Nation character values like value of religiosity, honesty, tolerance, discipline, hardworking, creativity, independence, democratic, curiosity, nation spirit, homeland affection, achievement appreciation, friendliness / communicativeness, peace-oriented, reading-oriented, environmental care, social care, and responsibility, honesty, justice, cooperation, confidence, survival, and logical thinking are decreased by mental of hedonism, individualism, consumptivimism, pragmatism, and materialism which start to encounter digital world development [21]. Character education becomes the hope to make the character of digital generation back and better. Therefore, innovation of method, strategy, and learning assessment must be done. Learners like teachers, lecturers, and tutors who have roles as the main actors playing crucial role in managing a learning which is oriented to the nation character forming.

The target of this character education is the students know, feel, and do good deeds. Through education character, the students are not only demanded to have various quotients like linguistics, logical mathematics, musical, spatial, visual, kinesthetic, interpersonal, but also they are prioritized of comprehending some quotients until forming personality which has characters and building harmony with self, other people, God, and environment. This target depends on the educators' competence in suing method and system of assessment in their learning processes [22]; [23].

\section{METHOD AND STRATEGY OF LEARNING IN CHARACTER EDUCATION}

When discussing about the component of education process, then the educators need to choose and use the method carefully which is in accordance with the development stage of students and the type of character that is willing to be improved and comprehended. According to Lickona, character education is conducted by using direct learning which is supported by the environment of family, class, school, and community which has character [24]. Hence, the method and the strategy of education must be also various. In the context of learning, methods of conversation, story, role-model providing, and habituation are proposed. These methods besides to fulfill active learning principle [25], it also fulfills direct learning principle [24]

First, it is called conversation method. Conversation method is a dialog of one another about a topic or character. Topic or character value that is selected must be real, for example topic about discipline, justice, tolerance, creativity, honesty, corruption, and so forth. The conversation points must be recorded, for example what and when it happens, why it happens, the party who is harmed and benefited, how it is solved, how and when I solve it, what betterment I do, and so forth. In a period, the educators can observe the comprehension. This method is considered well because it can make the problems provided become dynamic, every individual feels involved in the conversation process so that it avoids boredom, rises several feelings and impressions of students, every individual learn to respect opinions one another, and every individual can follow the conversation with a deep attention [24].

Second, it is telling story method. Telling story method is a classical method in education; however, telling story method in the context of character education is not only as a transfer of knowledge, but also it contains imperative or moral which forms character of students. Therefore, the story told must be based on the real experience especially the story of importance people affecting the life of community. The moral or character messages which are going to be delivered is as the final purpose of story and follow up in form of the intention of behavior change that will be done by students clearly. The intention of behavior changes as the follow up of learning must be specific, real, practical, and observed. The educators should prepare guidance of observation in form of 
flow chart which contains time, place, and frequency of a character done [24].

Third, it is making promise method. The educators need to ask students to make a promise for themselves. The student promises to make good deeds in a time. Making promise method in one side probably is contradictory with the paradigm of constructivism emphasizing on the learning independence of students without interference from other parties. However, in one side, promise is seen as an internal commitment of individual to do goodness, both for him and for environment [24].

Fourth, it is role-model providing method. Rolemodel providing method becomes the main method in planting, developing, and comprehending character values in the students. This is a living teaching method. Teaching becomes not effective if it is not supported by an action or a good living example from the educators in the school and from the parents in the house. England states that the best example of leadership is leadership by example. The educator is the person who gives example of good character for students. Education and teaching will be beneficial if the educator, which is the parents, have a good living example in the real life. The educators must become the witness of goodness, fairness, disciple, tolerance, piety, and others for the students. Hence, the educators become the example for the students. The loss of nation character today is due to the fact that many role models made as examples in family, school, community and government no longer becomes the character examples for the students because of selfishness, hedonism, and greediness mental, as well as pragmatic-temporal way of thinking which masters them [24].

Fifth, it is known as habituation method. Habituation is something which is intentionally done repeatedly in order that the thing becomes a habit. A good character of someone must be trained and habituated. This method is considered good because character can only be had if an attitude and a behavior are done repeatedly. If doing something repeatedly, then the thing will be ours. The learning theory of behaviorism emphasizes on the role of educators in habituating the students to perform good deeds, study hard habit, be honest, be responsible, work hard, discipline, respect one another, and so forth. Every character seems difficult to be comprehended, but because it is habituated, it will be our character at the end. A good habit which has been ours will be a character, because character is the attire and characteristic had by individual in a permanent period. Habituation method needs persistence and patience for the educators, because the imperative of behavior continuously will be boring [24].

The effectiveness of learning methods that have been explained towards character building of the students are supported and helped with learning management strategy and collaborative work of intercomponents of education [26].

First, it is learning management. Learning management covers physical and non-physical or social management. Educators and school need to manage a clean, comfortable, and wide management, so that it enables accessibility, mobility, interaction, and learning variation for students, and it enables the educators obtain and follow character development had by the students. Then, social environment management can be in form of patterns of educative interaction showing the warmth of love and compassion between educators and students in the learning process, including the use of interactive learning media. The learning situation, which is warm, close, and full of brotherhood as the situation experienced by the students in family will motivate them to feel happy and survive in a learning situation [26].

Second, it is called collaborative work. The effectiveness of character education methods can be done by the collaborative work among educators, students, and parents of students, as well as tutors in the activities of skill and passion development both in school and in community. It is important to build strong collaboration between school and family [24]. The effectiveness of collaborative work is done by using particular media, for example through routine meetings between teachers/school and parents of students, sending-receiving letters, and the use of "connecting book" or in the digital context nowadays, it can use Facebook account and WhatsApp to make coordination between teachers/school and parents of students easier. It is since the comprehension of character values is not only in the classroom and in the school, but also it is in the entire human life, like in family and community environment.

\section{LEARNING ASSESSMENT IN CHARACTER EDUCATION}

Because the main target of character education is action of values, then it gives effects on innovation of principle, target, implementation time, and assessment technique. First, it is principle and target of assessment. Learning assessment in character education is not only oriented on the measurement of learning result as what happens commonly in the learning evaluation, but also it is oriented on curriculum betterment including learning process, learning phase guidance, and students' learning motivation [4]; [5]. In line with this, there are three assessment targets in $21^{\text {st }}$ century namely: 1) thinking ability involves critical thinking, problem solving, creativity, and metacognition; 2) action assessment covers communication skill, collaborative work, digital awareness, visual literacy, and technology awareness; and 3) the ability to live together in the real world include the ability to live in a nation, global understanding, leadership and responsibility, and work 
skill [6]. These principles and targets of assessment focus on the character that is needed to work in today's era, both character which is related to relation ability, work ability, adaptation ability and the development of digital technology.

Second, it is implementation time of assessment. The assessment of character education is continuous meaning that it occurs during learning process and out of learning process. The experience of discussing, the process of finishing work, the activity of object observation, the activity of problem solving, the report of cooperative-collaborative or individual learning result are the opportunities for educators to do assessment for the students. Therefore, the assessment becomes daily activities as the learning activities which are done every day [27]. Continuous assessment must involve other parties like parents of the students, trainer or advisor of skill and passion development, both in the school and in the community environment. Hence, the educators can narrate character, passion, competence or quotient of their students completely.

Third, it is technique and form of assessment. The characteristic of continuous assessment and involves many parties demand the use of technique and form of assessment which are various. A continuous assessment needs technique and type of project assessment, portfolio, observation, selfassessment/reflection completed with appropriate assessment instruments [6]; [28].

Project-based assessment is the activity of assessing an assignment that must be completed time starting from planning, schedule arrangement, project accomplishment, report arrangement, process evaluation, and project result. The aspects which must be considered are: 1) management ability related to the relevance of material, time efficiency, searching ability, information finding as in line with the type of project assignment, and report writing; 2) the relevance of project assignment result compatibility with the subject materials given by the educators; 3 ) the authenticity of product of work result of students. Portfolio assessment is an assessment technique done by assessing work result of track record of the students in form of collection of assignment, work, academic and/or non-academic achievement, which are done by the students who portray passion, development, achievement, and creativity of the students in a period.

The observation of the students' ability can be done in the classroom during learning process. The aspect of observation covers the ability to express opinion, the ability of asking, cooperation, and others. The observation can also be done out of the classroom or in community. In order to support and complete observation technique out of the classroom or in the community, assessment technique in form of interview and questionnaire can also be done to know the character of the students in the real life [7]. Interview is done mainly with the people who know mostly the students. Self-assessment is an assessment technique in which the students are asked to assess themselves, regarding to academic and non-academic field in form of character or quotient regarding to relation with themselves, other people, God, and environment.

Techniques and instruments of assessment which have been explained previously are not only various, but also are authentic and comprehensive [29]; [6]; [30]. With various, authentic, and comprehensive assessment techniques and instruments, the educators obtain accurate and objective information about character, passion, and specific quotient had by the students. The objective information related to academic and nonacademic helps the educators to make learning motivation strategy for students further.

\section{CONCLUSION}

The progress of the digital world has penetrated every line of life. Its presence must be balanced with good character for its users. Therefore, the education carried out for the younger generation is not only oriented to mastering science and technology, but the formation of strong characters so that they can adjust to the development of the digital world. To achieve this goal requires the innovation of methods and assessment of learning. Learning methods that are used do not only emphasize aspects of moral knowledge and moral feelings but are prioritized on aspects of action or appreciation of moral values in real life. Furthermore, the assessment system is oriented towards improving the curriculum such as in the learning process, guiding the stages of learning, motivating students to learn, as well as continuous, authentic, and diverse assessments. Recommended assessment techniques are project appraisal, portfolio, observation, self-assessment, and interview. These valuation techniques are oriented to: 1) thinking skills, including critical thinking, problem solving, creative, and metacognition; 2) assessing actions, including communication, collaboration, digital literacy, visual literacy, and technology literacy; 3) assessing the ability to live together in the real world, including citizenship life skills, global understanding, leadership, responsibility, and work skills.

\section{REFERENCE}

[1] M. Nakayama, K. Mutsuura, and H. Yamamoto, "Impact of Learner's Characteristics and Learning Behavior on Learning Performance during a Fully Online Course.," Electronic Journal of e-Learning, Vol. 12 (4), pp. 394-408, 2014.

[2] A. Klašnja-Milićević, B. Vesin, M. Ivanović, Z. Budimac, and L. C. Jain, "E-Learning Systems: Intelligent Techniques for Personalization," Springer, Vol. 112, 2016.

[3] T. Lickona, "Educating for character: How our schools can teach respect and responsibility," New York: Brantam Book, 2009.

[4] W. J. Popham, “Assessment literacy overlooked: A teacher educator's confession," The Teacher Educator, Vol. 46 (4), pp. 265-273, 2011.

[5] P. Griffin, B. McGaw, and E. Care, "Assessment and Teaching of 21st Century Skills," New York: Springer, 2012. 
[6] L. M. Greenstein, "Assessing 21st century skills: A guide to evaluating mastery and authentic learning," London: Sage Publishing, 2012.

[7] P. Sahlberg, and H. Bagir, "Finnish lessons: mengajar lebih sedikit, belajar lebih banyak ala Finlandia," Jakarta: Kaifa, 2014.

[8] J. Webber, "Sartre's theory of character," European Journal of Philosophy, Vol. 14 (1), pp. 94-116, 2006

[9] V. Battistich, "Character education, prevention, and positive youth development," Washington DC: Character Education Partnership, 2005.

[10] S. Philips, "Refleksi Karakter Bangsa," Jakarta: Bumi Aksara, 2008.

[11] P. L. Glanzer, and A. J. Milson, "Legislating the good: A survey and evaluation of character education laws in the United States," Educational Policy, Vol. 20 (3), pp. 525-550, 2006.

[12] T. Lickona, E. Schaps, and C. Lewis, "Eleven principles of effective character education," Washington DC: Character Education Partnership, 2002.

[13] P. R. Indonesia, "Peraturan Pemerintah Republik Indonesia No. 32 Tahun 2013 tentang Perubahan Atas Peraturan Pemerintah No. 19 Tahun 2005 tentang Standar Nasional Pendidikan," Jakarta, 2013.

[14] N. Sudjana, "Cara Belajar Siswa Aktif dalam proses belajar mengajar bagaimana mengaktifkan siswa dalam belajar," Jakarta: PT Gramedia, 2008

[15] Dr. Sangidu, "Penelitian sastra: Pendekatan, teori, metode, teknik, dan kiat," Yogyakarta: Unit Penerbitan Sastra Asia barat UGM, 2004

[16] A. Sudrajat, "Pengertian Pendekatan, Strategi, Metode, Teknik, dan Model Pembelajaran," Bandung: Sinar Bar Algensindo, 2008

[17] D. Disdakmen, "Panduan penilaian untuk sekolah menengah atas," Jakarta:Dirjen Disdakmen, 2015.

[18] N. E. Gronlund, "Measurement and evaluation in teaching," New York: Macmillan Publishing Company, 1985.

[19] Depdiknas, "Peningkatan Kualitas Pembelajaran," Jakarta: Depdiknas, 2004.

[20] A. Syarbini, "Pendidikan Karakter Berbasis Keluarga," Yogyakarta: Ar-Ruzz Media, 2016.

[21] K. P. Nasional, "Pengembangan pendidikan budaya dan karakter bangsa," Jakarta: Puskur-Balitbang Kemdiknas, 2010.

[22] H. Gardner, "Frames of mind: The theory of multiple intelligences," New York: Basic Books, 2011.

[23] T. Armstrong, "Multiple intelligences in the classroom," Virginia USA: Ascd, 2009

[24] T. Lickona, "Character matters: How to help our children develop good judgment, integrity, and other essential virtues," New York: Simon and Schuster, 2004.

[25] M. Silberman, "Active learning: 101 strategi pembelajaran aktif,” Yogyakarta: Pustaka Insan Madani, 2009.

[26] Suyanto, dan A. Jihad, "Menjadi Guru Profesional (Strategi Meningkatkan Kualifikasi dan Kualitas Guru di Era Global)," Jakarta: Esensi Erlangga Group, 2013.

[27] B. B. Seels, and R. C. Richey, "Instructional technology: the definition and domain of the field," Washington DC Association for Educational Communications and Technology, 1994.

[28] M. Hosnan, "Pendekatan saintifik dan kontekstual dalam pembelajaran abad 21: Kunci sukses implementasi kurikulum 2013,” Bogor: Ghalia Indonesia, 2014

[29] T. R. Rosebrough, and R. G. Leverett, "Transformational teaching in the information age: Making why and how we teach relevant to students," Alexandria Virginia: ASCD, 2011.

[30] R. I. Arends, "Learning to Teach (Ninth Edition)," New York: Ma-CrawHill Companies Inc, 2012. 